\title{
Pénzügyi felügyeleti feladatokat kizárólagosan ellátó központi bankok Kelet-Közép-Európában ${ }^{1}$
}

\section{Central Banks with Exclusive Financial Supervisory Duties in Central and Eastern Europe ${ }^{1}$}

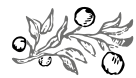

\section{Összefoglalás}

Számos modell létezik a pénzügyi felügyeleti szervek múködésére: megfigyelhetünk példákat arra, amikor a felügyeleti szervek tevékenységüket a központi banktól függetlenül látják el, vagy két (esetleg több) intézmény együttesen gyakorolja a felügyeletet az egyes szektorok fölött, bizonyos feladatköri megosztás alapján. Magyarország 2013ban egy olyan felügyeleti modell mellett döntött, amely alapján a központi bank kizárólagosan látja el a felügyeleti feladatokat. Régiónkat tágan értelmezve két országot találunk, amely ilyen modell szerint múködik: Csehország és Szlovákia. A tanulmány célja annak bemutatása, hogy a hazánkhoz hasonló modellt választó országok esetében mi volt a központi bankba integrált felügyeleti hatóságok kialakulásának háttere, milyen főbb felügyeleti kihívásokkal, kockázatokkal szembesültek ezen országok, továbbá milyen következtetéseket lehet levonni a felügyelési gyakorlatukból.

VArga Bence, vezetô felügyelô, Magyar Nemzeti Bank, doktorjelölt, Szegedi Tudományegyetem Gazdaságtudományi Kar (vargabe@mnb.hu). 
Varga Bence: Pénzügyi felügyeleti feladatokat kizárólagosan ellátó központi bankok...

Journal of Economic Literature (JEL) kódok: E58, G21, G23

Kulcsszavak: Csehország, Szlovákia, felügyeleti kihívások, központi bank, pénzügyi felügyelés

\section{Summary}

There are numerous patterns for the operation of financial supervisory bodies: some supervisory bodies operate independently from the central bank, or two (perhaps even more) institutions divide the duties and jointly supervise the individual sectors. In 2013, Hungary decided to adopt a scheme with the central bank's exclusive supervisory power. In the region, two other countries operate in a similar scheme: the Czech Republic and Slovakia. The paper aims to present the factors leading to the establishment of integrated central banks in countries that have chosen schemes like Hungary, the major supervisory challenges and risks, and the conclusions that may be drawn from their supervisory practice.

Journal of Economic Literature (JEL) codes: E58, G21, G23

Keywords: Czech Republic, Slovakia, supervisory challenges, central bank, financial supervision

\section{BEVEZETÉS}

Magyarországon a tervgazdaság idôszakának végén felügyeleti szempontból meghatározó változást az 1986. év jelentett, ekkor jött létre az Állami Biztosításfelügyelet. Ennek megalakítását újabb felügyeleti szervek létrehozása követte, így 1990-ben az Állami Bankfelügyelet és az Állami Értékpapír-felügyelet is létrejött. Néhány évvel késôbb, 1993-ban alakult meg az Állami Pénztárfelügyelet, és egy évvel késóbb, 1994-ben az Állami Értékpapír-felügyelet Állami Értékpapír- és Tôzsdefelügyeletre történô átnevezésével feladatkörét jelentôsen kibôvítették, többek között a tôzsdén forgalmazható áruk engedélyezésével. A felügyeleti szervek integrációjának elsô lépését jelentette az Állami Bankfelügyelet, valamint az Állami Értékpapír- és Tózsdefelügyelet integrációja és Állami Pénz- és Tókepiaci Felügyeletként való megalakulása. Az integráció következô szintjét pedig a Pénzügyi Szervezetek Állami Felügyeletének 2000. április 1-jei létrejötte jelentette, mely a korábbi ágazati felügyeletek összeolvadásából (Állami Pénz- és Tókepiaci Felügyelet, Állami Biztosításfelügyelet, Állami Pénztárfelügyelet) alakult meg.

A hazai bankfelügyelés történetében újabb mérföldkônek számított a Pénzügyi Szervezetek Állami Felügyeletének jegybankba történô integrációja, 2013. október 1. napjával a hagyományosnak tekinthetố jegybanki funkciók kiegészültek felügyeleti funkciókkal is, így a mikro- és makroprudenciális eszközök már egy intézményen belül összpontosulnak. Számos országban rendelkezik a központi bank bizonyos felügyeleti funkciókkal, Kelet-Közép-Európában jelenleg hazánkon kívül még két országban múködik központi bankba integrált, valamennyi felügyeleti feladatot (is) kizárólagosan 
ellátó intézmény: Csehországban és Szlovákiában.² A tanulmány bemutatja, hogy az említett országokban hogyan alakult ki a központi bankba integrált felügyelés, valamint azt, hogy milyen fóbb felügyeleti kihívások jelentkeztek és jelentkeznek napjainkban a két országban. Természetesen a pénzügyi felügyelés önálló vagy integrált módjából nem lehet egyértelmúen következtetnünk a felmerüló felügyeleti kihívásokra, hiszen azt egyéb tényezók is meghatározzák (pl. megvalósított monetáris politika, valuta külsố és belsố stabilitása stb.), továbbá a felügyeleti struktúra nem determinálja a felügyelés hatékonyságát vagy hatékonytalanságát sem. Az alkalmazott felügyeleti „rezsim” ugyanakkor mindenképpen hatással van a pénzügyi rendszer stabilitására, így a hasonló felügyeleti felépítés szerint múködő országokat érintő kihívások ismerete hozzájárulhat a hazánkban jelentkezô felügyeleti kihívások hatékony kezeléséhez.

\section{JELLEMZŐ TENDENGIÁK, ÁLTALÁNOS TAPASZTALATOK}

A nemzetközi tendenciákat tekintve megállapítható, hogy nem létezik legjobb gyakorlat a felügyeleti struktúra kialakítására, és ezen túlmenôen az EU-ban sem létezik arra vonatkozó iránymutatás vagy javaslat, hogy milyen típusú felügyeleti struktúra valósítandó meg. Az EU-ban a felügyeleti struktúrák meglehetősen változatos képet mutatnak, az 1990-es években a régiónkban található országokra alapvetóen kétféle struktúra volt jellemző. Az egyikben a hitelintézetek felügyeletét az adott ország központi bankja látta el, a többi szektor (biztosítói, pénztár és tôkepiac) felügyelete általában a pénzügyminisztériumon belül múködött. A másik, szintén elterjedt struktúra szerint a hitelintézetek felügyelete önállóan, a többi szektor felügyelete pedig vagy valamelyik minisztérium részeként, vagy szintén önállóan múködött. Integrációs folyamatok elôször a skandináv országokban jelentek meg (Taylor-Fleming, 1999), amelyek már számos ország - beleértve hazánkat is - felügyeleti struktúráját meghatározzák. Az integrációs folyamatokat azon felismerés indította el, hogy a létrejött pénzügyi csoportok, a megjelent, korábbiakhoz képest komplexebb (pl. pénzpiaci és biztosítói elemeket ötvözô) termékek szükségessé tették a felügyeletek közötti szorosabb együttmúködést és a kapcsolódó információk megfelelóbb áramlását, ezenfelül elvetették a pénzügyi dereguláció elvének szükségességét. Az integrációs folyamatok erôsödése esetén továbbá az egyes szektorokra vonatkozó szabályozás és az alkalmazott felügyeleti módszertan egységessége is könnyebben megvalósulhat (Lentner, 2013; Seregdi, 2016). Mindazonáltal általánosan tapasztalható jelenség, hogy a 2008-ban kitört gazdasági és pénzügyi válság hatására a jegybankok feladatköre kibôvült bizonyos szintû felügyeleti feladatokkal (ECB, 2017), és újabb tendenciaként hangsúlyossá vált az EU-szintû együttes felügyelés (az Európai Központi Bank részvételével) is a nemzeti hatóságok szerepének megtartása mellett. A felügyeleti keretrendszer erôsítése érdekében kiemelt szerepet kapott a felügyeleti konvergencia erôsítése (a nemzeti felügyeleti hatóságok tevékenységének független szerv általi felülvizsgálatával), a piaci információk elsô kézból való megszerzése (a különbözó piacok kelló ismerete), a belsô kockázatmérési módszerek fejlesztése (kockázattudatosság növelése), valamint a szabályozói útmutatók és ajánlások kidolgozása, színvonaluk javítása (EC, 2017). 
Természetesen napjainkban is vannak elkülönült felügyeleti rendszert előnyben részesítô országok (pl. Ausztrália, Kanada, Japán, Svájc), melyek között nagy múltú, stabilitást jelképezô központi bankot is találhatunk. A központi bankba integrált felügyelet múködésével kapcsolatban és a szervezetileg elkülönült felügyelés mellett is számos érv felsorolható (Gyura-Szombati, 2009; MNB, 2013). Elôbbi tekintetében példaként említhetô, hogy a vonatkozó felelôsségi körök tisztázottabbak, a célok öszszehangolása egyértelmúbb, az erős jegybanki eszköztár erősítheti a felügyeleti funkciókat is, nagyobb hangsúlyt kaphat a makroprudenciális szemlélet, és a jegybank bankközi piaci szereplőként elsố kézbő́l származó információkkal rendelkezik a piaci folyamatokról, így hozzájárulva a hatékonyabb felügyeléshez. Utóbbival összefüggésben pedig elmondható, hogy több hatóság az eltérô felügyeleti megközelítésből következóen több kockázatot azonosíthat, nem fordulhat elô, hogy a felügyelés egyéb funkciók ellátása (pl. monetáris politika) miatt háttérbe szorul, valamint erôsebb jogosítványokkal (pl. jogérvényesítés tekintetében) rendelkezhet a felügyelés önálló szervezetként.

\section{SZLOVÁK I A}

\section{A központi bankba integrált felügyelet kialakulása}

Történelmi okok miatt Szlovákia és Csehország központi bankjának kialakulása szorosan összekapcsolódott. 1950-ben jött létre a Csehszlovák Állami Bank, ami a központosított gazdaságirányítás gyakorlatának megfelelôen átvett valamennyi, korábban más bankokban, például a Csehszlovák Nemzeti Bankban és a Slovenská Tatrabankában meglévố funkciókat. A Csehszlovák Állami Banknak felügyeleti mandátuma ekkor még - hasonlóan más, központosított gazdaságirányítás keretében múködô központi bankhoz - nem volt, és ilyen tevékenységet ellátó intézményre az adott gazdasági keretek között nem is volt igazán szükség. A felügyeleti funkciók megjelenésére a kétszintû́ bankrendszer 1990. évi létrejöttével nyílt lehetôség, így alakult meg 1991-ben a Csehszlovák Nemzeti Bankon belüli felügyeleti fóosztály, mely azonban meglehetôsen alacsony személyi létszámmal (8 fő) múködött, és a múködésére vonatkozó jogszabályi keretrendszer sem volt megfelelô. Ennek volt betudható, hogy a bankfelügyeleti feladatokat elsôdlegesen a Pénzügyminisztérium látta el, míg a felügyeleti terület kapacitásait - nehezen magyarázható módon - a központi bank múködésével kapcsolatos jogszabályok implementálásával összefüggő feladatok kötötték le (Tuma, 2002).

A Csehszlovák Állami Bank függetlensége számos tekintetben megkérdôjelezhetô volt (pl. pénzkibocsátással összefüggésben), illetôleg a monetáris politika is sajátosan valósult meg az adott gazdasági viszonyok következtében. Kapcsolódó reformkezdeményezésekre már 1968-ban sor került, önálló, független központi bank létrehozatalára azonban majd csak a Csehszlovák Köztársaság felbomlását követôen, 1993-ban kerülhetett sor. Ebben az évben jött létre a Szlovák Nemzeti Bank, mely felügyeleti funkciókkal is rendelkezett, szervezetén belül a bankfelügyelés ellátására - a koráb- 
biakhoz hasonlóan - külön fốosztály jött létre (Hlavaty-Zelinka, 2003). A szlovák felügyeleti rendszer 2006. január 1. napjától vált integrálttá, ettől az évtôl ugyanis a Pénzpiaci Hatóság (Financial Market Authority, FMA) által korábban ellátott tôke-, nyugdíj- és biztosítói piacok felügyeletét a Szlovák Nemzeti Bank gyakorolja, és ezen tevékenységét azóta is kizárólagosan, egyéb intézmények bevonása nélkül látja el (NBS, 2015).

\section{A szlovák pénzügyi felügyelést érintô fóbb kihívások, kockázatok}

Szlovákiában a felügyeleti integrációs folyamat relatíve korán elindult, hiszen 1993-ban már tapasztalhatók voltak ilyen irányú törekvések. A felügyelés hatékonysága azonban még 2002-ben is meglehetôsen alacsonynak volt értékelhetô számos tekintetben, annak ellenére, hogy az ebben az évben hatályba lépett banktörvény erôsebb felügyeleti keretrendszert biztosított a pénzügyi intézmények vállalatirányítása, kockázatkezelése, jogérvényesítése és konszolidált felügyelése vonatkozásában (IMF, 2002). Az erôsebb felügyeleti keretrendszer például abban volt tetten érhetô, hogy korábban a felügyeleti tevékenység kizárólag helyszínen kívüli felügyelést jelentett, míg 2002-ben a felügyeleti eszköztár kiegészült a helyszíni felügyelés gyakorlatával (TWB, 1994). Az alacsony felügyeleti hatékonyság a bankfelügyelés esetében elsôsorban a nem kellôen proaktív és a kockázatalapú megközelítés hiányosságaira, míg a bankszektoron kívüli felügyelés tekintetében a nem megfelelô szabályozói környezetre volt visszavezethetô, illetôleg különösen ez utóbbi esetben a pénzmosás-megelôzési irányelvek implementációjával összefüggésben is elmaradás volt tapasztalható (IMF, 2002). Bár meg kell említenünk, hogy a felügyelet nem kellóen hatékony múködéséhez nyilvánvalóan az is hozzájárult, hogy a 2002-ben megalakult FMA ekkor még nem szerezhetett kelló szintú felügyeleti tapasztalatot (NBS, 2003). A felügyelés nem megfelelő hatékonysága mellett annak széttagoltságát mutatja, hogy egyes biztosítótársaságok (pl. Supplementary Pension Insurance Companies) felügyelete a Munkaügyi Minisztérium, a Pénzügyminisztérium és a Társadalombiztosítási Hivatal között oszlott meg. A szlovák felügyelés számára továbbá kihívást jelentett azon intézmények felügyelete, amelyek magas megtérülést ígérve gyüjtöttek visszafizetendô pénzeszközöket a gazdasági szereplôktôl, valamint a nemzetközi számviteli standardok (International Accounting Standards) adaptációjának és implementációjának hiánya következtében megvalósult pénzügyi kimutatások megbízhatóságával kapcsolatos fenntartások is nehezítették a felügyelést (IMF, 2002). 2007-re ugyanakkor a felügyelés hatékonysága érdemben javult, és a felügyeleti keretrendszer is jelentôsen megerôsödött, valamint a 2004. évi európai uniós tagsággal párhuzamosan a szabályozói környezet is érdemi javulást mutatott, az uniós direktívák (pl. Capital Requirements Directives) szlovák jogszabályokba való átültetésével kapcsolatban azonban még ekkor is hiányosságok voltak tapasztalhatók, bár ez nem volt szlovák sajátosságnak tekinthetô. Szintén javítandó volt a külföldi felügyeleti hatóságokkal történô együttmúködés és információmegosztás, valamint az új pénzügyi instrumentumokkal összefüggő kockázatok kezeléséhez kapcsolódó kompetenciák bôvítésére is szükség volt (IMF, 2007). 
1. ábra: A szlovák pénzügyi felügyelésre ható föbb tényezôk

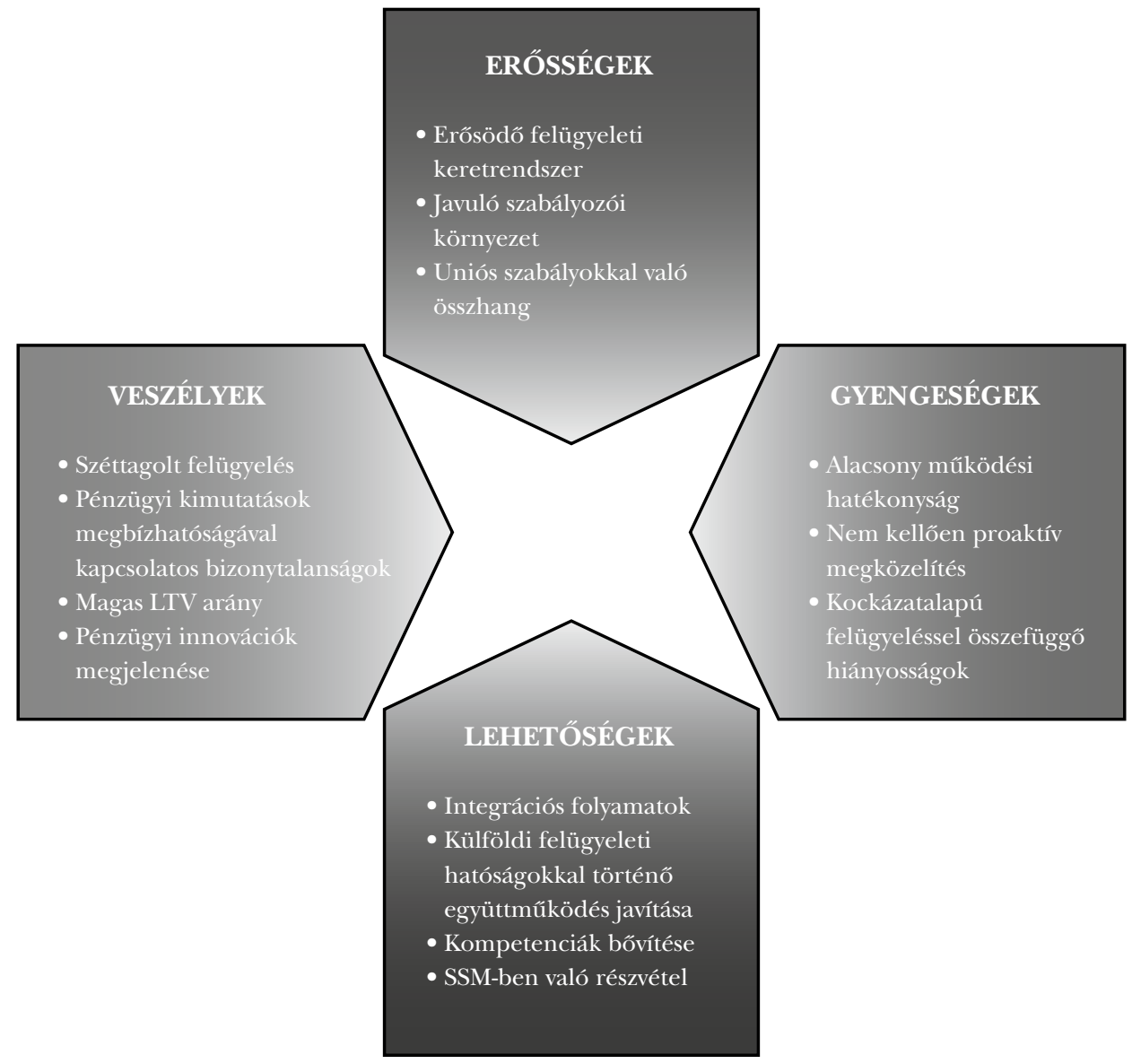

Forrás: Saját szerkesztés

2017-re a szabályozói és felügyeleti keretrendszer tovább fejlődött, az uniós jogszabályokkal és direktívákkal való összhang jelenleg biztosított, az egységes felügyeleti mechanizmus (Single Supervisory Mechanism, SSM) keretében pedig a felügyelés szoros koordinációja már megvalósul. 2016-ban elfogadásra került az új ingatlanhitelezésre vonatkozó törvény, melynek keretében a Szlovák Nemzeti Bank a jövedelemhez viszonyított adósságszolgálat és a hitelfedezeti arány (loan-to-value, LTV) tekintetében további szigorításokat vezetett be. A 2017-ben hatályba lépett, fogyasztói hitelezésre vonatkozó kiegészített törvény elơírja, hogy fogyasztói hiteligénylésnél igazolni kell az adósságszolgálati képességet is. A felügyeleti tevékenység hatékonyságának fokozásához ugyanakkor további prudenciális szempontú szigorítások szükségesek, mint például a bázeli ajánlásoknak megfelelôen a jelzáloghitelek esetében a kockázati súlyok növelése a befektetési célú ingatlanok esetében, vagy abban az esetben, ha az LTV meghaladja a 80\%-ot. Szükséges továbbá az LTV-limit csökkentése, mivel jelenleg az a 
harmadik legmagasabb (közel 100\%) az Európai Unióban. A fogyasztói hitelezésnél tapasztalt portfólióromlás kezelésére a Szlovák Nemzeti Bank a hitelezési standardokra vonatkozóan szabályozás kialakítását tervezi (IMF, 2017). Kihívást jelenthet a szlovák felügyelés számára a peer-to-peer (P2P) hitelezés, mely a 2012. év végén jelent meg Szlovákiában. Bár még jelenleg nem tekinthetô számottevônek, mindössze 0,1\%os piaci részesedéssel rendelkezett 2015-ben, növekedési potenciálja azonban jelentôs lehet. A mérsékeltebb elterjedést magyarázza, hogy Szlovákia viszonylagosan konzervatív a pénzügyi innovációkat illetôen, aminek köszönhetôen viszont a 2008-ban kitört gazdasági és pénzügyi válság sem érintette olyan érzékenyen gazdasági helyzetét. Az elmúlt idôszakban egyes terméktípusokra (kollektív befektetési formák) vonatkozó jogszabályi kiegészítések jelentôsen növelték a közösségi hitelezés szabályozottságának lefedettségét, külön jogszabály azonban továbbra sem került elfogadásra (Soltés-Stofa, 2016). A P2P szabályozottságának kialakítását egyes piaci szereplők is javasolták, mivel az hozzájárulhat a platformokkal kapcsolatos bizalom növekedéséhez.

\section{CsehorszÁG}

\section{A központi bankba integrált felügyelet kialakulása}

A kétszintû bankrendszer 1990. évi létrejöttét követő években megindult a bankszektor szereplői számának jelentôs növekedése, és 1993-ra már ötvenet meghaladó számban múködött bank Csehországban. A pénzügyi felügyelés és szabályozás viszont ekkor még kezdetlegesnek volt tekinthetô, mivel a kapcsolódó keretrendszer megfogalmazására és meghatározására is csak ebben az idôszakban került sor (Tuma, 2002), mely körülmény jelentôs hatással volt a késôbb megjelenô felügyeleti kihívásokra. 2006-ot megelőzôen a bankfelügyeleti feladatokat a Cseh Nemzeti Bank, a biztosítói és nyugdíjalapok felügyeletét a Pénzügyminisztérium alá tartozó Biztosítói és Nyugdíjalapok Felügyeleti Hivatala, a tôkepiac felügyeletét a Cseh Értékpapír-bizottság, a hitelszövetkezetek és takarékszövetkezetek felügyeletét pedig a Szövetkezetek Felügyeleti Hivatala látta el. A felügyelésben fordulópontot Szlovákiához hasonlóan Csehországban is a 2006. év jelentett, ettôl az évtől kezdődôen - néhány hónappal a szlovák integrációs törekvéseket követôen - a korábban négy felügyeleti szerv által ellátott feladatok egyetlen szerv, az 1993-ban létrejött Cseh Nemzeti Bank alá tartozó Pénzpiaci Bizottság (Financial Market Committee) feladatkörébe tartoznak, így a Cseh Nemzeti Bank felügyeleti tevékenységét már integráltan, valamennyi szektor (pénz-, tôke-, nyugdíjés biztosítói piacok) esetében ellátja. Az integrációra Csehországban elsôsorban azért került sor, hogy megelőzzék az egyes felügyeleti szervek közötti hatékonytalanságot eredményezô feladatköri átfedéseket (Kucerová, 2010).

\section{A cseh pénzügyi felügyelést érintő fóbb kihívások, kockázatok}

Csehországban a központi banki és felügyeleti integrációval kapcsolatos nézetek Szlovákiához képest késôbb jelentek meg, ezen kezdeményezések ugyanakkor Cseh- 
ország esetében is ugyanazon évben, 2006-ban jutottak érvényre, a cseh felügyeletnek viszont teljesen eltérố kihívásokkal kellett szembenéznie. A két lépcsôben végrehajtott konszolidációs program (1991 és 1994; illetve 1995 és 1996 között), majd az azt követő́n megvalósított stabilizációs program sikeresnek volt tekinthető, hiszen elóbbinél sor került az életképtelen bankok felszámolására, a fenntartható múködésú bankok tôkehelyzetének megszilárdítására, valamint konzervatív hitelezési alapelvek gyakorlatba történô átültetésére, míg utóbbinál megvalósult a nemteljesítő kitettségek részbeni megvásárlása (Tuma, 2002). Mindezen intézkedések ellenére azonban az 1990-es évek második felére (1997-1999) a magas vállalati nemteljesító hitelek (30\%-ot meghaladó mértékben) bankválságot idéztek eló (Frait et al., 2011). Ennek hatására tizenöt kis- és középbank szüntette be tevékenységét, és a négy legnagyobb bank (Czech Savings Bank, Commercial Bank, Czechoslovak Trade Bank, Investment Bank) a végrehajtott portfóliótisztítást (a rossz besorolású hiteleket az állami tulajdonú Czech Consolidation Bank vette át) követôen külföldi tulajdonba került. A válság hatására a bankok száma 1995 és 2002 között 54-rôl 24-re csökkent, mely magában hordozta a bankokkal szembeni bizalom megingását is. Ahogyan az 1990 utáni elsố bank bukásának esete (ti. Banka Bohemia) mutatja, a bukást annak a közvéleményben való elterjedése okozta, hogy az általa nyújtott bankgaranciák mögött nem áll megfeleló fedezet. A banki bukások meghatározó része azonban nem a reputációs, hanem a hitelezési vagy egyéb területen elkövetett csalások, bennfentes információval való visszaélések miatt következtek be, illetôleg több esetben előfordult az is, hogy az adott bank olyan vállalat(ok)nak nyújtott hitelt, amely(ek) üzleti tevékenységet nem folytattak, és egyáltalán munkavállalói sem voltak. A pénzintézeti bukások okainak feltárását nehezítették a cseh bírósági rendszerben tapasztalt nehézségek: az 1995-ben bedólt Industrial Credit Bankkal kapcsolatban tizenöt évet kellett várni az ítélet meghozataláig (Dubská, 2013). Mindezekból következtethetünk arra, hogy a cseh pénzügyi felügyelés a kezdeti időszakban inkább „light touch" megközelítést követett, hiszen a banküzem több területe is felderítetlen maradt a felügyelés számára, szemben a klasszikus megközelítéssel, mely minden részletre kiterjedô felügyelést tart célravezetônek. 2016-ot megelőzôen a felügyeléssel összefüggó hiányosságok alapvetôen a felügyeleti szakértôk alacsony számával, a felügyelet korlátozott beavatkozási lehetôségével (pl. alacsony tôkemegfelelés esetén), a leányvállalatok és anyavállalatok közötti jövedelemáramlás nem kellôen szoros monitorozásával és a pénzügyi csoportok esetén alkalmazott felügyeleti keretrendszer nem megfelelő kidolgozottságával álltak összefüggésben. 2016 után ugyanakkor az említett hiányosságok jelentôs részben megszúntek; hiányosság a nagykockázati kitettségekre meghatározott limitek implementálásával kapcsolatban említhetô meg (IMF, 2016).

A bankszektorban meghatározó volt a külföldi tulajdon részaránya (2010-ben ez mintegy 80\%-ot ért el), az említett négy legnagyobb bank az ügyfélhitelek 96\%-át nyújtotta, így jelentôs koncentráció is tapasztalható volt. Emellett növekvô tendenciát mutatott a nem banki pénzügyi közvetítők térnyerése is, melyek nem pénzügyi vállalatok és háztartások hitelellátásában betöltött részaránya 2005-re közel 20\%-ra emel- 
2. ábra: A cseh pénzügyi felügyelésre ható fóbb tényezôk

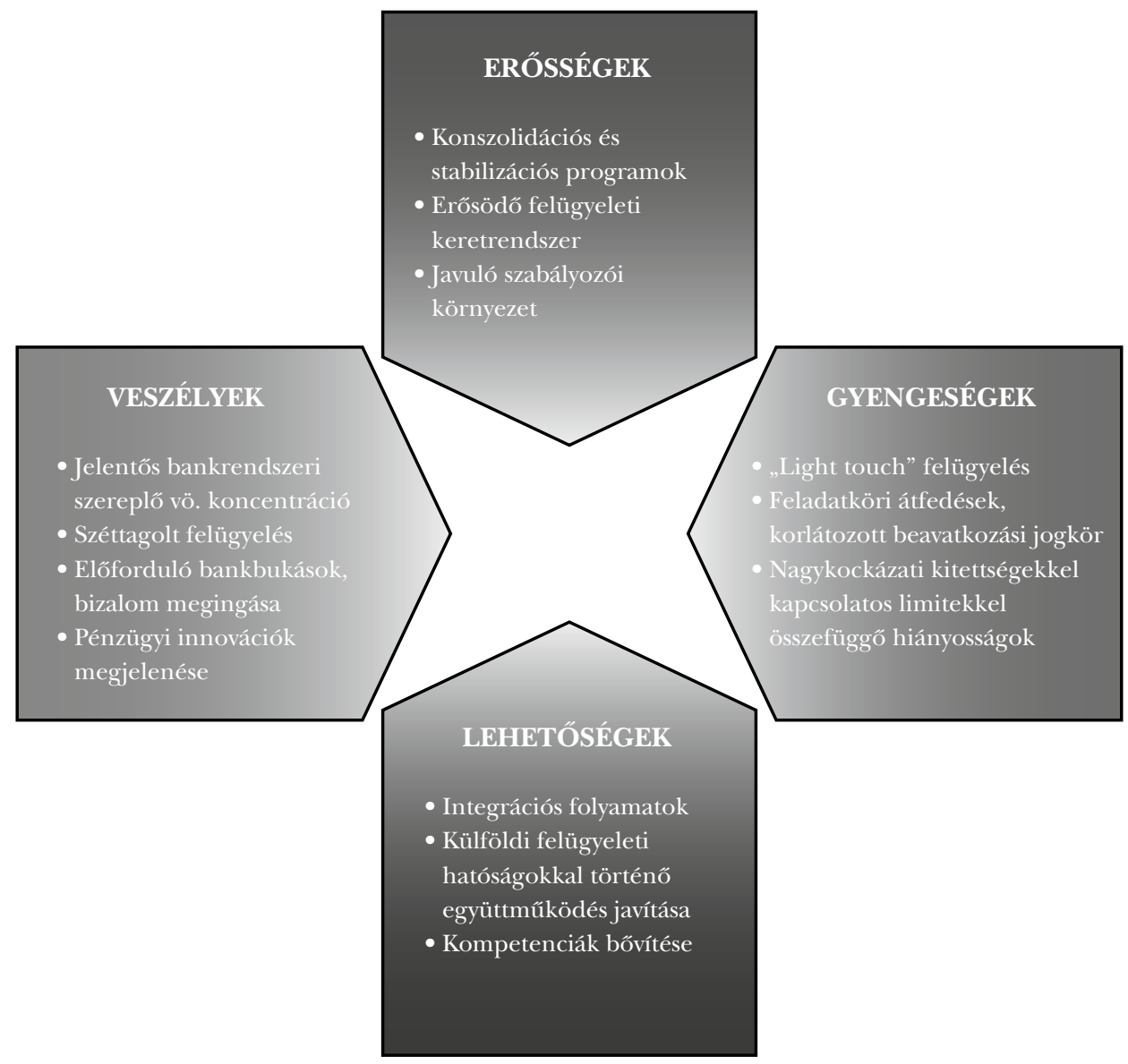

Forrás: Saját szerkesztés

kedett. Bár a késôbbiekben ezen arány a bankok növekvố versenye és az adópolitikai módosításoknak köszönhetôen némileg mérséklôdött, az továbbra is jelentôs maradt (Tomšík, 2015). A kockázatosnak tekinthetô eszközök (pl. eszközökkel fedezett értékpapírok) nem voltak meghatározók a pénzintézetek portfóliójában, így a 2008-ban kitört gazdasági és pénzügyi válság pénzintézetekre való hatása mérsékelt volt (Dubská, 2013). A nem banki hitelnyújtást erôsítette a közösségi hitelezési formák megjelenése, melyek közül a legjelentősebb az ún. jutalomalapú (reward-based) hitelezés, ennek nagyságrendje 2015-ben elérte az 1,7 millió eurót, de a Zonky.cz 2015. évi alapítását követően a P2P-hitelezés is jelentôssé vált. A közösségi hitelezést érintő, két kiemelt kihívást Csehországban a jogi szabályozás optimális szintjének meghatározása és ezzel összefüggésben a fizetések feldolgozásával kapcsolatos nehézségek jelentik. Jelenleg a cseh jogszabályok nem tartalmaznak a közösségi hitelezésre vonatkozó specifikus rendelkezéseket, hanem annak egyes altípusaira vonatkozóan találhatók szabályok (pl. 
adatvédelmi törvényben), illetőleg tôkealapú (equity-based) platform múködtetése esetén az azt múködtetô társaságnak befektetési vállalkozásnak kell lennie, így ehhez tőkepiaci törvénynek megfelelő engedély birtoklása szükséges. A közösségi hitelezés nagyobb térnyerése várható a jövőben, melyre a Fundlift 2016. évi megjelenése is utal (CrowdfundingHub, 2016).

\section{KÖVETKEZTETÉSEK}

Mindhárom visegrádi ország különbözô utat járt be a pénzügyi felügyelés és a központi banki funkciók kialakítása tekintetében, a folyamat kimenetele ugyanakkor megegyezett: a felügyeleti feladatok a központi banki funkciók mellett egy intézményen, a központi bankon belül helyezkednek el. Szlovákia és Csehország példája következtetni enged arra, hogy önmagában nem elegendô a konszolidációra, a stabilitás elérésére való törekvés, amennyiben a felügyeleti keretrendszer „gondozása”, folyamatos aktualizálása nem kap kellô hangsúlyt, a pénzügyi közvetítô rendszerben megnövekvố kockázatok miatt éppen a stabilitás elérésére irányuló törekvések sikeressége lehet kérdéses. Mélyebb önvizsgálatra ösztönözhet az a két ország esetében megfigyelhetô jelenség, hogy ugyan az integrációs folyamatok egyértelmúen azonosíthatóak nemzetközi szinten, mégis, az integrált múködés nyújtotta előnyök teljes körú érvényesülése nem törvényszerú, annak elérése érdekében folyamatos beavatkozásra van szükség mind felügyeleti, mind pedig jegybanki részrôl.

Éppen ezért megfontolandó lehet ezen országokkal szorosabb felügyeleti együttmúködés kialakítása annak érdekében, hogy a központi bankba integrált felügyeleti múködésból eredô sajátosságok, elônyök még inkább felderítésre és kiaknázásra kerülhessenek. Szintén érdemes lehet a felmerült kockázatok felügyeleti kezelésének megosztása, mely a határon átnyúló pénzügyi szolgáltatások (pl. közösségi hitelezés) következtében rendkívül fontos valamennyi érintett ország esetében. Erre annál is inkább szükség lehet, mert tágan értelmezett régiónkban is csak az említett országokban (az Európai Unióban pedig még két országban) múködik a hazaihoz hasonló központi banki-felügyeleti modell.

\section{JEGYZETEK}

1 Jelen cikk a szerzô nézeteit tartalmazza, és nem feltétlenül tükrözi a Magyar Nemzeti Bank hivatalos álláspontját.

2 Az Európai Unióban az említett országokon kívül még Írországban és Litvániában múködik központi bankba integrált felügyelet (Horáková-Jordan, 2013).

\section{FELHASZNÁLT IRODALOM}

CrowdfundingHub (2016): Current State of Crowdfunding in Europe. An Overview of the Crowdfunding Industry in More Than 25 Countries: Trends, Volumes \& Regulations. CrowdfundingHub, Amsterdam, www.sbs.ox.ac.uk/sites/default/files/Entrepreneurship_Centre/Docs/OxEPR2/current-state-crowdfunding-europe-2016.pdf (Letöltés: 2017. augusztus 29.). 
Dubská, Drahomíra (2013): The Czech Banking Sector: Two Decades with the Shuttle Changes. Statistika, Vol. 93, No. 1, 71-81, www.czso.cz/documents/10180/20550309/180213q1_dubska.pdf/0470c17cb6e9-41be-bb62-93737e59eafc?version=1.0 (Letöltés: 2017. augusztus 15.).

EC (2017): Reinforcing Integrated Supervision to Strengthen Capital Markets Union and Financial Integration in a Changing Environment. European Commission, COM (2017) 542 final, http://ec.europa.eu/finance/ docs/law/170920-communication-esas_en.pdf.

ECB (2017): Faraway or close? Supervisors and Central Bankers. Speech by Ignazio Angeloni, Member of the Supervisory Board of the ECB, Halle, 2 February, www.bankingsupervision.europa.eu/press/speeches/ date/2017/html/se170202_1.en.html.

Frait, Jan - Geršl, Adam - Seidler, Jakub (2011): Credit Growth and Financial Stability in the Czech Republic. The World Bank, Policy Research Working Paper, No. 5771, https://doi.org/10.1596/1813-9450-5771.

Gyura Gábor - Szombati Anikó (2009): Fókuszban a rendszerkockázat - A pénzügyi felügyelés új irányai itthon és külföldön. MNB-Szemle, december, 6-12.

Hlavatý, Egon - Zelinka, Ivan (2003): The Origin of the National Bank of Slovakia. The Result of a Long Journey to National Sovereignty. BIATEC Publications, Vol. 11, No. 7, 25-30, www.nbs.sk/_img/Documents/BIATEC/BIA07_03/25_30.pdf (Letöltés: 2017. augusztus 9.).

Horáková, Martina - Jordan, Amy (eds.) (2013): How Countries Supervise their Banks, Insurers and Securities Market 2013. Central Banking Publications, London.

IMF (2002): Financial System Stability Assessment - Slovak Republic. IMF Country Report 02/198, International Monetary Fund, Washington, D. C., www.imf.org/external/pubs/ft/scr/2002/cr02198.pdf.

IMF (2007): Slovak Republic: Financial System Stability Assessment Update, Including Reports on the Observance of Standards and Codes on the Following Topics: Banking Supervision and Insurance Regulation. IMF Country Report 07/243, International Monetary Fund, Washington, D. C., www.imf.org/external/pubs/ft/ scr/2007/cr07243.pdf.

IMF (2016): Czech Republic: Article IV Consultation - Press Release; Staff Report; and Statement by the Executive Director for Czech Republic. IMF Country Report 16/213, International Monetary Fund, Washington, D. C., www.imf.org/external/pubs/ft/scr/2016/cr16213.pdf.

IMF (2017): Slovak Republic: Article IV Consultation - Press Release; Staff Report; and Informational Annex for Slovak Republic. IMF Country Report 17/71, International Monetary Fund, Washington, D. C., www.imf. org/en/Publications/CR/Issues/2017/03/23/Slovak-Republic-2017-Article-IV-Consultation-Press-Release-Staff-Report-and-Informational-44750.

Kucerová, Zuzana (2010): The Impact of Financial Crisis on Financial Supervision in the EU, the USA and the Czech Republic. Bulletin of the Transilvania University of Braşov, Vol. 3, No. 52, 271-280, http://webbut.unitbv. ro/bu2010/Series\%20V/BULETIN\%20V\%20PDF/271\%20Kukerova.pdf (Letöltés: 2017. augusztus 14.).

Lentner Csaba (2013): A bankszabályozás tudományos rendszertana és fejlôdéstörténete. In: Lentner Csaba (szerk.): Bankmenedzsment. Bankszabályozás, pénzügyi fogyasztóvédelem. Nemzeti Közszolgálati és Tankönyvkiadó, Budapest, 27-85.

MNB (2013): Az MNB pénzügyi felügyeleti funkcióinak megerôsítése. Magyar Nemzeti Bank, Budapest, www. mnb.hu/letoltes/felugyelet-hu.pdf.

NBS (2003): Financial Stability Report. Národná Banka Slovenska, Bratislava, www.nbs.sk/_img/Documents/ ZAKLNBS\%5CPUBLIK\%5CSFS\%5CSFS2003A.PDF.

NBS (2015): The National Bank of Slovakia... its Tasks and Activities. Národná Banka Slovenska, Bratislava, www.nbs.sk/_img/Documents/_Publikacie/OstatnePublik/BROZURA_NBS_GB.pdf.

Seregdi László (2016): A pénzügyi felügyeletek közötti nemzetközi együttmüködés gyakorlata, a továbbfejlesztés szükségessége és lehetséges irányai. PhD-értekezés, Kaposvári Egyetem, Gazdaságtudományi Kar, Kaposvár.

Soltés, Michal - Stofa, Tomás (2016): Crowdfunding - The Case of Slovakia and the Czech Republic. Quality Innovation Prosperity, Vol. 20, No. 2, 89-104, www.qip-journal.eu/index.php/QIP/article/download/807/693, https://doi.org/10.12776/qip.v20i2.807.

Taylor, Michael - Fleming, Alex (1999): Integrated Financial Supervision. Lessons of Scandinavian Experience. Finance and Development, Vol. 26, No. 4, 42-45, www.imf.org/external/pubs/ft/fandd/1999/12/ pdf/taylor.pdf (Letöltés: 2017. december 13.). 
Tomšík, Vladimír (2015): Changes in the Czech Republic's Financial Intermediation During the last Decade. BIS Papers, No. 83, Bank for International Settlements, 137-142, www.bis.org/publ/bppdf/ bispap83h.pdf (Letöltés: 2017. augusztus 15.).

Tuma, Zdenek (2002): Banking Sector Development in the Czech Republic. Österreichische Nationalbank, Vienna, www.cnb.cz/miranda2/export/sites/www.cnb.cz/en/public/media_service/conferences/speeches/download/tuma_200212_vien.pdf (Letöltés: 2017. augusztus 16.).

The World Bank (1994): Slovakia - Restructuring for Recovery. A World Bank Country Study. The World Bank, Washington, D. C., http://documents.worldbank.org/curated/en/615841468759587882/pdf/ multi0page.pdf. 